\section{CAST IRONS IN AUTOMOBILE CONSTRUCTION}

D RING the last ten years the progress made in automobile development and production has been due, in very large measure, to improvements in the materials of construction. Of these, cast iron ranks as one of the most important. The great majority of the cars currently purchased in the United Kingdom are of the 'quantity production' class. It is the use of this type of car that is considered by E. C. Toghill and R. V. Dowle in a paper on the "Applications of Cast Iron in Modern Automobile Construction" recently published ( $J$. Inst. Automobile Eng., March 1940).

The object of the paper is to bring to the notice of the automobile engineer and designer some of the irons with special properties for specific applications, and to show that the grading of cast iron and the choice of the correct grade for the purpose are as important as in the case of steels.

The influence of nickel, chromium, molybdenum and copper in cast iron is summarized as follows. In connexion with the use of special elements, the important role of nickel in automobile cast irons is pointed out. Nickel is a graphitizing element, being in this respect about one third as powerful as silicon, but whereas silicon coarsens the grain and the graphite, nickel has a refining effect. In addition, the presence of the nickel renders the iron more uniform and less sensitive to sectional change. A correct balance of nickel and silicon is an important factor in the production of an alloy having the best properties. For example, if no allowance is made for the graphitizing influence of nickel, that is, if no proportionate reduction of the silicon is made, little increase in strength is observed up to about 1.5 per cent of nickel, after which, strength and hardness gradually increase. If, on the other hand, the silicon content is suitably adjusted, additions of $0 \cdot 5-5$ per cent of nickel will give $10-50$ per cent increase in tensile strength.

Strength, hardness, depth of chill, and resistance to heat wear and corrosion are increased by the presence of suitable amounts of chromium, and provided that the carbide is not in massive condition, the shock-resisting ability of the iron is also enhanced.

Molybdenum refines the grain of the iron and the graphite, and has a very beneficial effect on shock resistance. Molybdenum stabilizes carbides and increases tensile and transverse strength; it also produces a slight improvement in corrosion- and heatresistance and in machinability. In many respects, copper produces similar effects to nickel. Tensile and transverse strength are improved by the presence of small amounts of copper, the effect being most pronounced in low carbon irons. Fluidity of cast iron is also improved by the presence of copper.

Messrs. Toghill and Dowle direct attention to the extensive research in progress under the joint auspices of the Institution of Mechanical Engineers and the British Cast Iron Research Association, in which a collation is being made of the range of high-duty cast irons and of their properties and uses in general engineering. The aim of the work is to provide the automobile and other engineering industries with data which will facilitate the choice of the grades of cast iron suitable for widely diverse applications.

\section{APPOINTMENTS VACANT}

APPLICATIONS are invited for the following appointments on or before the dates mentioned:

Graduate in Pure Sciznch able to take Chrmistry, Physics and MATHEMATICS TO 1ST YEAR DEGREE STANDARD, and a WORKSHOP INSTRUCTOR also capable of taking some MACAINE DRAWING-The Principal, County Technical College, Worksop, Notts (August 15). CHIEF Assistant Enarines to the Port of Bristol Authority-The General Manager, Docks Office, Queen Square, Bristol 1 (August, 19). ChiEF LABORATORY Assistant in the County Bacteriological and Pathological Laboratories-Dr. T. N. V. Potts, County Medical Officer, County Hall, Wakefield (August 19).

Eddcationat Psychologist-The Director of Education, Fducation Department, Town Hall, Barnsley (August 21).

\section{REPORTS AND OTHER PUBLICATIONS}

(not included in the monthly Books Supplement) Great Britain and Ireland

Association of British Chemical Manufacturers. Directory of British Fine Chemicals produced by Members of the Association. Pp. 80. (London: Association of British Chemical Manufacturers.)
Gratis. Proceedings of the Royal Society of Edinburgh, Session 1939-1940.
Vol. 60, Part 2, No. 14: The Genetical and Mechanical Properties of the Sex Chromosome, vi. Hexacentrus mundus. By Dr. P. C. Koller. Pp. $174-181$. 9d. Vol. 60, Part 2, No. 15: A Theoretical Atomic
Distribution Curve for Liquid Argon at $90^{\circ} \mathrm{K}$. By G. S. Rushbrooke. Pp. 182-191. 1s. Vol. 60, Part 2, No. 16: The Loss of Heat by Conduction from the Earth's Crust in Britain. By Dr. E. M. Anderson. London: Williams and Norgate, Ltd.)

Transactions of the Royal Society of Edinburgh. Vol. 60, Part 1, No. 6 : The Geology of the Highland Border from Glen Almond to Glen Artney. By Dr. Douglas A. Allen. Pp. 171-193+1 plate +1 map. (Edinburgh : Robert Grant and Son, Ltd. ; London : Williams
and Norgate, Ltd.)
[267. $[267$
Prospectus of the London School of Economics and Political Science (University of London) for the Forty-sixth Session, 1940-41. Pp. 146. (Cambridge: London School of Economics and Political Science.) 18.

Sheffield City Libraries. Research Bulletin No. 4 : Sheet and Strip, Part 2: Sheet and Strip Finishing Processes and Special Sheet Materials. Pp, 22. (Sheffield : Central Library.) 3d.

\section{Other Countries}

Field Museum of Natural History. Botanical Series, Vol. 22, No. 2 : Studies of American Plants, 10. By Paul C. Standley. (Publication 472.) Pp. 63-130. (Chicago: Field Museum of Natural History.) Observatoire de Zi-ka-wei. Annales de l'Observatoire astronomique Observatoire de Zi-ka-wei. Annales de l’Observatoire astronomique
de Zô-s (Chine). Tome 21, Fase. 4: Tables des planetes 296, 711, d36. Par le P. E. de la Villemarqué. Pp. 44. (Zi-ka-wei : Observatoire 736. Par le P. E. de la Villemarqué. Pp. 44. (Zi-ka-wei : Observatoire
de Zi-ka-wei.)
[177

Commonwealth of Australia: Council for Scientiflc and Industrial Research. Bulletin No. 132: The Wood Anatomy of some Australian Lauraces with Methods for their Identification. By H. E. Dadswell and Audrey M. Eckersley. (Division of Forest Products, Technical Paper No. 34.) Pp. $48+8$ plates. (Melbourne: Government
Printer.)

Burma Meteorological Department. Meteorological Organization for Airmen. Pp. iv +33. (Rangoon : Government Printing and Stationery
Office.)

Agriculture and Animal Husbandry in India, 1937-38. Pp. $v+416$.

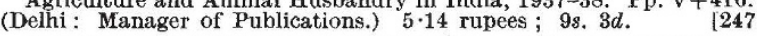

Imperial Council of Agricultural Research. Miscellaneous Bulletin No. 33: Selected Clinical Articles-1: A Few Cases of Johne's Disease in Sheep, by Muhammad Rahim-Ud-Din; 2: A Case of Pregnancy in the Mammary Gland, by C. D. Uttangi : 3 : An Unusual Case of Microfllarial Granuloma on the Prepuce of a Bull, by $\mathbf{R}$. C. Nathani and N. S. Sankaranarayanan. Pp. 10+4 plates. (Delhi:
Manager of Publications.) 9 annas: $10 d$. Imperial Council of Agricultural Research. Proceedings of the
Third Meeting of the Animal Husbandry Wing of the Board of Agriculture and Animal Husbandry in India, held at New Delhi from Agriculture and Animal Husbandry in India, held at New Delhi from
(Simla : Government of India Press.)
[247 Appendices. Pp. iii 307 . Canada: Department of Mines and Resources: Mines and Geology Branch, Ceologicai Survey. Paper 40-2: Wildcat Hills Map-Area, East Half, Alberta. By C. o. Hage. Pp. ii $+9+1$ map. 10 cents. Paper 40-3: Preliminary Map, Michiwacho Lake, Abitibi Territory, Quebec. By H. H. Beach. 1 map. 10 cents. Paper 40-4: Prelim inary Map, Mechamego Lake, Abitibi Territory, Quebec. By H. H. Beach. 1 map. 10 cents. Paper 40-5: Preliminary Map, Fish Creek, Alberta. By G. S. Hume. 1 map. 10 cents. Paper 40-7: Preliminary Map, Gordon Lake South, Northwest Territories. By J. F. Heuderson. 1 map. 10 cents. Paper 40-9: Preliminary Map. Gordon Lake, Northwest Territories. By J. F. Henderson. 1 map.
10 cents. (Ottawa : King's Printer.) 10 cents. (Ottawa : King's Printer.) $[297$ f the Adult Japanese Beetle. By I. M. Hawley and F. W. Metzger Pp. 32. (Washington, D.C.: Government Printing Office.) 5 cents. [297 